\title{
BATCH ADSORPTION AND ISOTHERM STUDIES FOR THE REMOVAL OF MALACHITE GREEN AND REACTIVE RED 4 DYES BY USING AC-MnO2-NC PREPARED FROM Typha angustat $L$.
}

\author{
M. Santhi ${ }^{1, *}$, P. E. Kumar ${ }^{1}$ and M. Sathya ${ }^{2,3}$ \\ ${ }^{1}$ Department of Chemistry, Erode Arts and Science College, Erode-638 009, TamilNadu, India. \\ ${ }^{2}$ Research \& Development Centre, Bharathiar University, Coimbatore-641046, \\ ${ }^{3}$ Department of Chemistry, Nandha College of Technology, Erode-638052, TamilNadu, India. \\ * E-mail: santhisendil@gmail.com
}

\begin{abstract}
The potential of using Typha Angustata L modified $\mathrm{AC}-\mathrm{MnO}_{2}-\mathrm{NC}$ to eliminate the dyes namely Malachite Green and Reactive Red 4 dyes are studied. The result of more than a few parameters such as adsorbent dosage, contact time, temperature, the initial concentration of the adsorbate and $\mathrm{pH}$ has been evaluated. Tempkin, Halsey, Langmuir, Dubinin-Radushkevich and Freundlich isotherms are too studied. The lessons exposed that $\mathrm{AC}-\mathrm{MnO}_{2}-\mathrm{NC}$ is appropriate to employ as an adsorbent to take away both Malachite Green and Reactive Red 4 dyes.

Keywords: Malachite Green, Reactive Red 4, $\mathrm{AC}-\mathrm{MnO}_{2}-\mathrm{NC}$, Isotherm.
\end{abstract}

(C) RASĀYAN. All rights reserved

\section{INTRODUCTION}

In current time, a serious environmental problem was arising due to the vast and increasing the uses of a variety of dyes. So, the water becomes more contaminated. Many industries such as textile, plastics, dyestuff's and paper use dyes so as to color their products and also chomp through a considerable amount of water ${ }^{1}$. The rapid development of the textile industry in developing countries has triggered an increase in pollution of the aquatic environment ${ }^{2}$. A significant quantity of devastating water is generated having sulpHides, heavy metals, chlorine, a highly fluctuating $\mathrm{pH}$ salts, COD concentration ,a large number of suspended solids and temperature ${ }^{3}$. Many of the organic dyes are dangerous and may distress food chain and even aquatic life. Discharge of these dyes in a watercourse is aesthetically undesirable. Due to the concentrated color, they diminish sunlight diffusion into water hence disturbing aquatic plants, which eventually upset the aquatic ecosystem; in addition, they are toxic to humans also.

In an effort to crack dye pollution troubles, methods like biological treatments, coagulation, membrane separation, photodegradation, reverse osmosis, chemical oxidation, and adsorption have been used; but the highly effective method is adsorption process. Adsorption procedure is functioning in ordinary chemical, biological and physical systems, and is broadly used in industrial applications such as synthetic resins and activated charcoal. Carbons with brilliant specific functionalities and surface properties must be urbanized to generate a lofty affinity for adsorbate adsorption. An extensive range of materials such as silk cotton fiber ${ }^{4}$, black tea leaves ${ }^{5}, \operatorname{cocoa}^{6}$, almond shell ${ }^{7}$, mango leaves ${ }^{8}$, saw dust ${ }^{9}$, Jambonut ${ }^{10}$,Borassus flabellifer ${ }^{11}$, Passiflora Foetida ${ }^{12}$ and animal bone ${ }^{13}$ are used as a low cost adsorbent. In this current learning, Typha Angustata L was chosen as the confined inexpensive adsorbent and it can be renewed into nanocomposite. The majority of the studies described that the adapted adsorbents are capable in compulsory either the cationic (or) anionic group but not equally. Yet, a combination of dissimilar types of dyes is regularly originated in the manufacturing effluents. In our sustained attempt to

Rasayan J. Chem., 11(4), 1423-1432(2018)

http://dx.doi.org/10.31788/RJC.2018.1143066

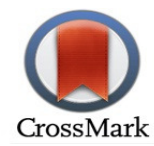


Vol. 11 | No. 4 |1423 - 1432| October - December | 2018

utilize economical resources for the exclusion of crude pollutants, we have analyzed the presentation of $\mathrm{AC}-\mathrm{MnO}_{2}-\mathrm{NC}$ from Typha Angustata L as an adsorbent for Malachite Green and Reactive Red dyes.

\section{EXPERIMENTAL}

\section{Preparation of Sorbate}

A Malachite Green having molecular formula $\mathrm{C}_{23} \mathrm{H}_{25} \mathrm{~N}_{2} \mathrm{Cl}$, the molecular weight of $364.92 \mathrm{~g} \mathrm{~mol}^{-1}$ with C.I. 42000 and wavelength $\left(\lambda_{\max }\right)$ of $617 \mathrm{~nm}$ was chosen as the adsorbate. A Reactive Red 4 having molecular formula $\mathrm{C}_{32} \mathrm{H}_{19} \mathrm{~N}_{8} \mathrm{Na}_{4} \mathrm{Cl}$, Mol Wt of 995.23 with CI No.18105 and wavelength ( $\lambda$ max) of $517 \mathrm{~nm}$ was chosen as the adsorbate.

A hoard solution of $1000 \mathrm{mg} / \mathrm{l}$ was arranged and the functioning solutions were organized by diluting the hoard solution with deionized water as required.

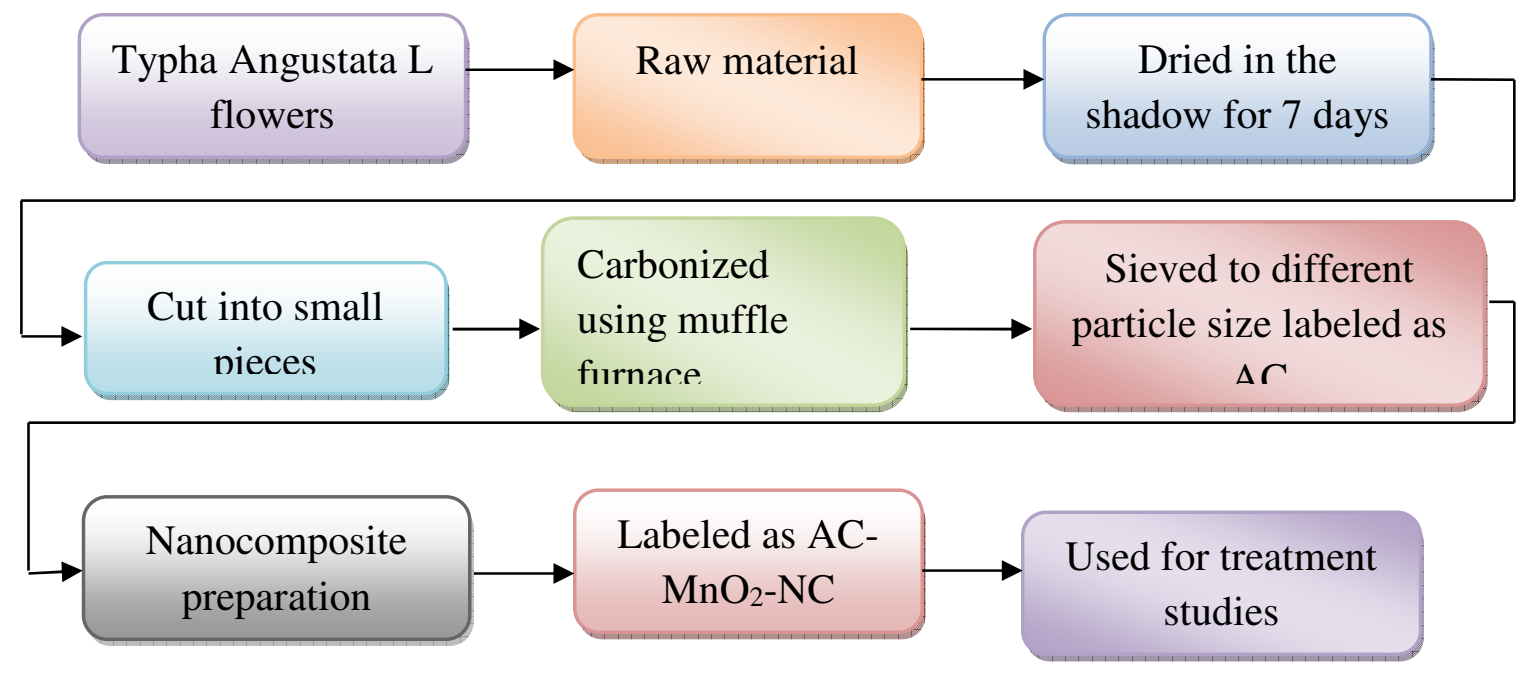

\section{Methodology}

Fig.-1: Flow Chart for the Preparation of $\mathrm{AC}-\mathrm{MnO}_{2}-\mathrm{NC}$

In each adsorption experiment, $50 \mathrm{~mL}$ of a dye solution with a known concentration was added to $100 \mathrm{mg}$ of $\mathrm{AC}-\mathrm{MnO}_{2}-\mathrm{NC}$ in a $250 \mathrm{ml}$ glass-stoppered flask at $30^{\circ} \pm 0.5^{\circ} \mathrm{C}$, and the mixture was stirred on a mechanical shaker at $150 \mathrm{rpm} \mathrm{min}$. The samples were withdrawn during stirring at preset time intervals, and the adsorbent was separated from the solution by centrifugation (Research centrifuge, Remi Scientific Works, Mumbai) at $4500 \mathrm{rpm} \mathrm{min}^{-1}$ for $5 \mathrm{~min}$. The absorbance of the supernatant solution was estimated to determine the residual dye concentration, and was measured before and after treatment with doa uble beam spectropHotometer (HITACHI U 2000 SpectropHotometer). All experiments were carried out twice, and the concentrations given are average values. The initial dye concentration in the test solution and the adsorbent dosage were varied to investigate their effect on the adsorption kinetics. The effect of $\mathrm{pH}$ was observed by studying the adsorption of dye over the $\mathrm{pH}$ range from 3 to 13 . The $\mathrm{pH}$ of the dye solution was adjusted by using $\mathrm{NaOH}$ or $\mathrm{HCl}$ solution and a $\mathrm{pH}$ meter. The sorption studies were carried out at different temperatures $\left(30^{\circ}, 40^{\circ}, 50^{\circ}, 60^{\circ} \mathrm{C}\right)$. This is used to determine the effect of temperature on the thermodynamic parameters. The amount of adsorption at time $\mathrm{t}, \mathrm{q}_{\mathrm{t}}(\mathrm{mg} / \mathrm{g})$, was designed via the next the principle:

$\mathrm{q}_{\mathrm{t}}=\left(\mathrm{C}_{0}-\mathrm{C}_{\mathrm{t}}\right) \mathrm{V} / \mathrm{W}$

Where , $\mathrm{C}_{0}\left(\mathrm{mgL}^{-1}\right)$ is the initial concentration of the dye in solution. adsorption, $\mathrm{C}_{\mathrm{t}}\left(\mathrm{mgL}^{-1}\right)$ is the liquid pHase concentrations of dye at any time, $\mathrm{V}$ is the volume of the solution (L) and $\mathrm{W}$ is the mass of dry adsorbent (g).

$\mathrm{q}_{\mathrm{e}}(\mathrm{mg} / \mathrm{g})$ is the amount of equilibrium was calculated using the formula:

$\mathrm{q}_{\mathrm{e}}=\left(\mathrm{C}_{0}-\mathrm{C}_{\mathrm{e}}\right) \mathrm{V} / \mathrm{W}$ 
Everyplace $\mathrm{C}_{\mathrm{e}}\left(\mathrm{mgL}^{-1}\right)$ and $\mathrm{C}_{0}$ are the liquid-pHase concentrations of dye initially and at equilibrium. The dye removal percentage can be calculated as follows:

$(\%)$ of dye removal $=\left[\left(\mathrm{C}_{0}-\mathrm{C}_{\mathrm{e}}\right) /\left(\mathrm{C}_{0}\right)\right] \mathrm{X} 100$

Where $\mathrm{C}_{0}$ and $\mathrm{C}_{\mathrm{e}}\left(\mathrm{mgL}^{-1}\right)$ are the initial and equilibrium concentrations of the dye in solution.

\section{Effects of Initial Dye Concentration Vs Agitation Time}

\section{RESULTS AND DISCUSSION}

Belongings of initial dye concentration $(10,20,30$ and $40 \mathrm{mg} / \mathrm{L})$ and agitation time on the elimination of MG and RR 4 by adsorbent are offered in Graph-1(a\&b). The removal percentage of MG increased with increase in agitation time and it will be decreased from 97.59 to 53.89 as the initial dye concentration was increased from 10 to $40 \mathrm{mg} / \mathrm{L}$ with a fixed carbon concentration of $100 \mathrm{mg} / 50 \mathrm{~mL}$ at room temperature $\left(30^{\circ} \mathrm{C}\right)$ respectively. In the case of RR4 it will be decreased from 99.05 to 58.58 percentage. It is lucid that the exclusion of the dye depends on the initial concentration. The deletion curves are smooth, single and continuous leading to saturation.

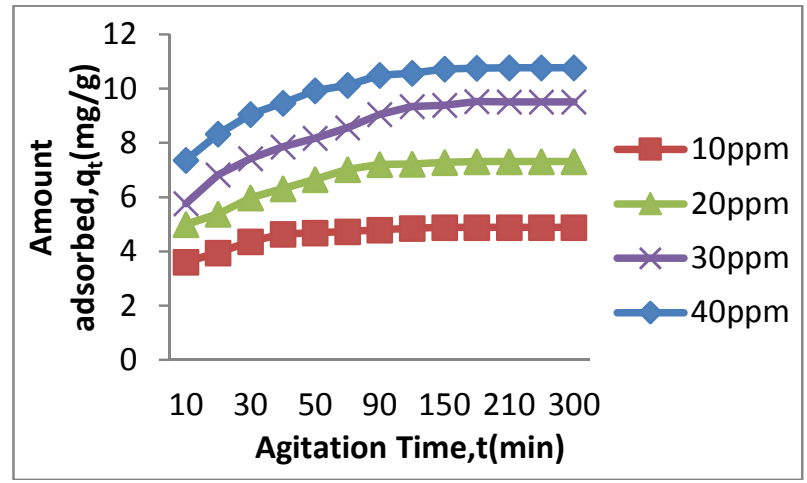

Graph-1a:Effects of initial dye concentration and agitation time on the removal of Malachite Green onto $\mathrm{AC}-\mathrm{MnO}_{2}-\mathrm{NC}$

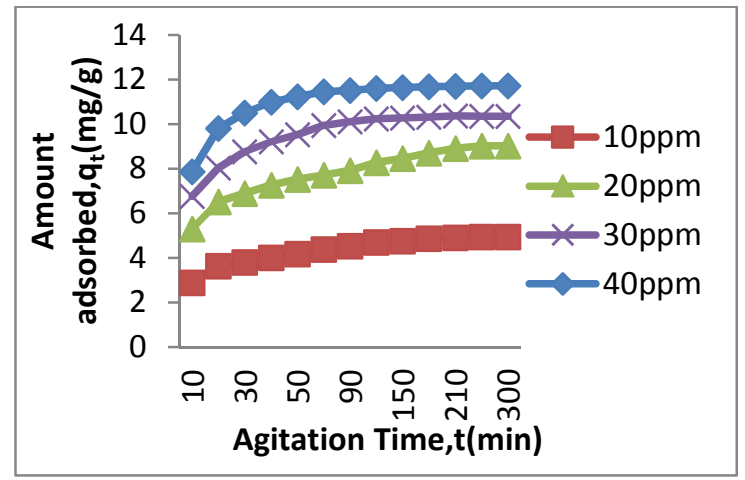

Graph-1b: Effects of initial dye concentration and agitation time on the removal of Reactive Red 4 onto $\mathrm{AC}-\mathrm{MnO}_{2}-\mathrm{NC}$

\section{Effect of Adsorbent Quantity}

The different adsorbent quantity was tested for the dye concentrations $10,20,30$ and $40 \mathrm{mg} / \mathrm{L}$ to the elimination of MG and RR4 by adsorbent are presented in Graph-2(a\&b) (10mg to 600mg/50ml). Increasing adsorbent concentration the adsorption also increases; this is owing to the availability of more adsorption site and increase in surface area. So the finest amount of adsorbent dose was $100 \mathrm{mg} / 50 \mathrm{ml}$.

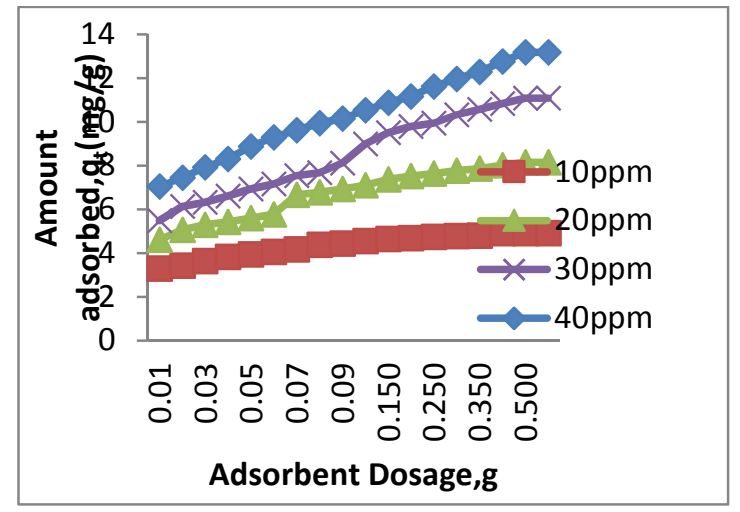

Graph-2a:Effect of adsorbent quantity on the removal of Malachite Green against $\mathrm{AC}-\mathrm{MnO}_{2}-\mathrm{NC}$

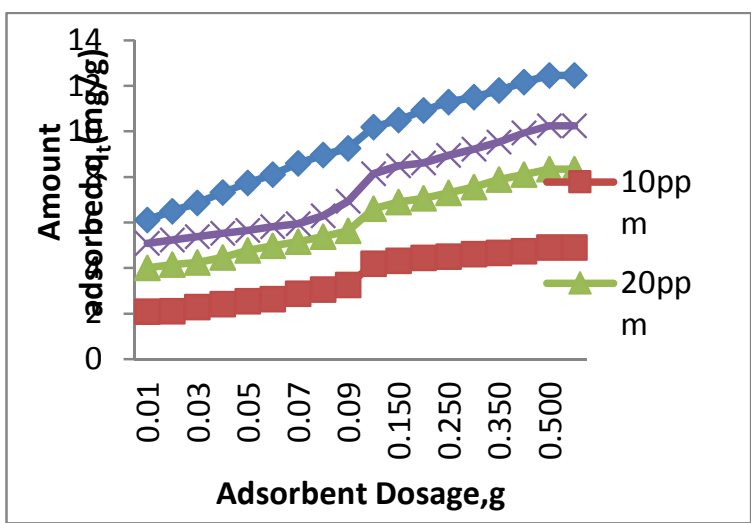

GrapH-2b: Effect of adsorbent dose on Removal of Reactive Red 4 on Adsorbent 
RASĀYAN J. Chem.

Vol. 11 | No. 4 |1423 - 1432| October - December | 2018

\section{Effect of pH}

The adsorption of dye solution on the adsorbent surface is highly influenced by the solution $\mathrm{pH}$. The adsorption capability of $\mathrm{AC}-\mathrm{MnO}_{2}-\mathrm{NC}$ against the solution $\mathrm{pH}$ is studied by varying the $\mathrm{pH}$ of the solution from 2.0 to 12.0 using dil. $\mathrm{HCl}$ and $\mathrm{NaOH}$ solutions for a fixed $\mathrm{MG}$ and $\mathrm{RR} 4$ concentration of $40 \mathrm{ppm}$. The surface properties of the activated carbon also play a significant role in the $\mathrm{pH}$-dependent adsorption of dye in solution. The percent elimination of MG increases from 8.65 to57.36\% (Graph-3a); of initial dye concentration of 40ppm with the increase in initial $\mathrm{pH}$ of dye solutions from 2 to 10 with fixed $\mathrm{AC}-\mathrm{MnO}_{2}$-NC. In that case for $\mathrm{AC}-\mathrm{MnO}_{2}-\mathrm{NC}$ removal of reactive dye, $\mathrm{RR} 4$ decreased from 92.25 to $58.58 \%$ (Graph-3b) with an initial dye concentration of 40ppm. It is revealed from GrapHs an appreciable removal of dyes occurred at acidic $\mathrm{pH}$ for the anionic dyes (Reactive dyes) and at alkaline $\mathrm{pH}$ for basic dyes (Malachite Green) suggests that the adsorption is chemisorptive in nature.

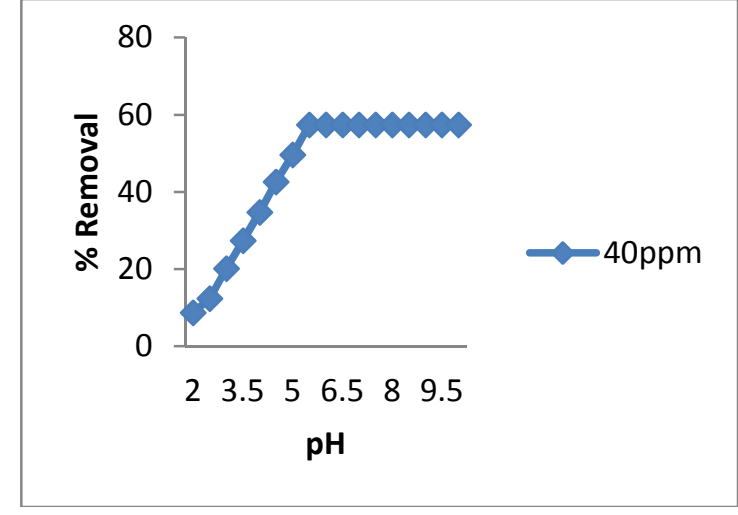

Graph-3a: Cause of $\mathrm{pH}$ of dye solution on the removal of Malachite Green on $\mathrm{AC}-\mathrm{MnO}_{2}-\mathrm{NC}$

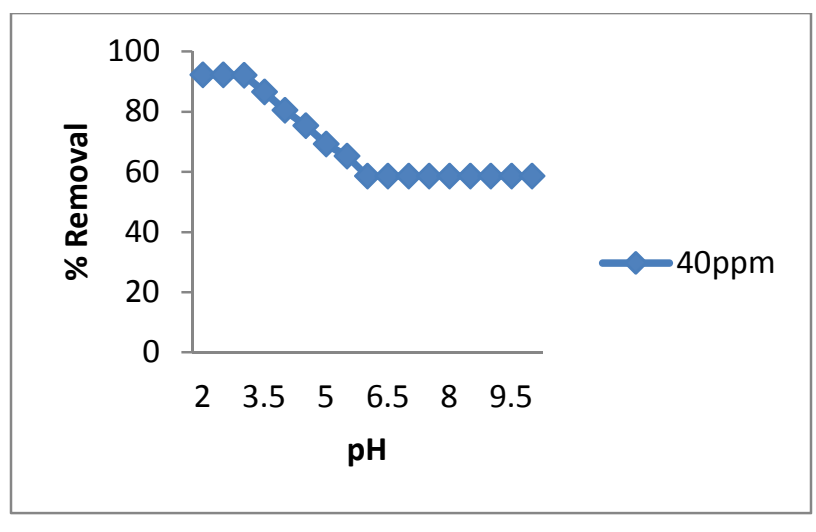

Graph-3b: Cause of $\mathrm{pH}$ of dye solution on the removal of Reactive Red 4 on $\mathrm{AC}-\mathrm{MnO}_{2}-\mathrm{NC}$

\section{Cause of Temperature}

The influence of temperature on the adsorption of $\mathrm{MG}$ and $\mathrm{RR} 4$ by $\mathrm{AC}-\mathrm{MnO}_{2}-\mathrm{NC}$ is shown in Graph4(a\&b).The uptake of $\mathrm{MG}$ and $\mathrm{RR} 4$ by $\mathrm{AC}-\mathrm{MnO}_{2}-\mathrm{NC}$ increases from 53.89 to $63.18 \%$ and 58.28 to $76.04 \%$ when the solution temperature increased from 30 to $45^{\circ} \mathrm{C}$. The enhanced adsorption at the high temperature indicated the endothermic nature of $\mathrm{MG}$ and $\mathrm{RR} 4$ adsorption onto the $\mathrm{AC}-\mathrm{MnO}_{2}-\mathrm{NC}_{\text {surface. }}$ At high temperature, the pores of the adsorbent are widened, which can accommodate more solutes. Another fact is that, at high temperature, the mobility of the MG and RR4 dyes increases. In these study, the amount of dye removed at equilibrium, with increases with increase in temperature indicates it is endothermic in nature. ${ }^{14}$

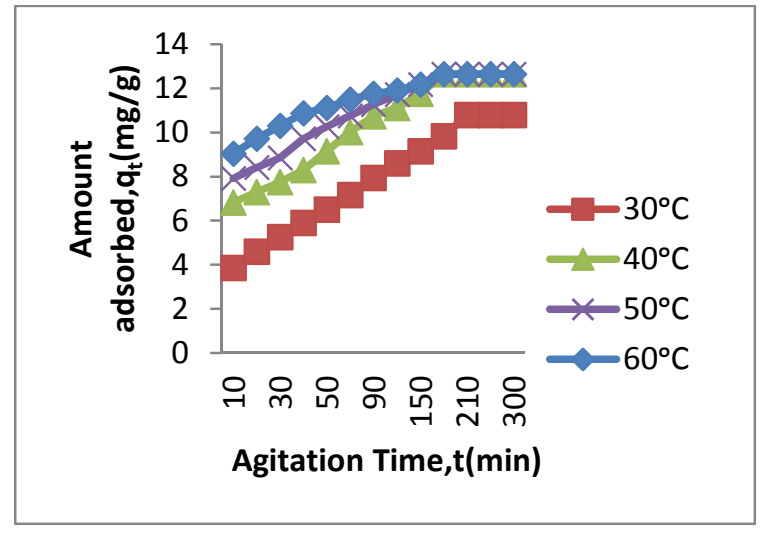

Graph-4a: The outcome of temperature on the removal of Malachite Green onto $\mathrm{AC}-\mathrm{MnO}_{2}-\mathrm{NC}$

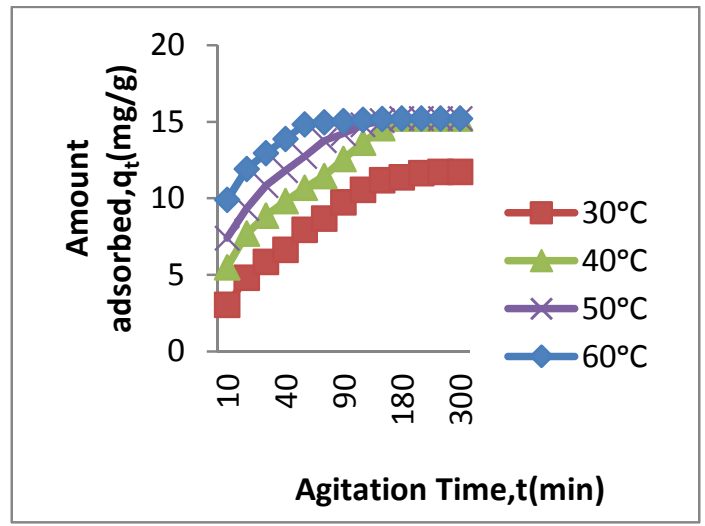

Graph-4b: The outcome of temperature on the removal of Reactive Red 4 onto $\mathrm{AC}-\mathrm{MnO}_{2}-\mathrm{NC}$ 
RASĀYAN J. Chem.

Vol. 11 | No. 4 |1423 - 1432| October - December | 2018

\section{Adsorption Isotherm}

Adsorption equilibrium statistics and properties, generally notorious as adsorption isotherms, Which explain how adsorbate (pollutant) work together with the adsorbent resources and demonstrate how they are decisive in optimizing the value of adsorbents. As a result, the association of equilibrium data by any hypothetical or experimental equation is fundamental to the matter-of-fact plan and process of adsorption scheme. So as to optimize the intend of the adsorption arrangement to eliminate dyes from effluents, it is significant to create the main suitable connection for the equilibrium $\operatorname{arch}^{15}$. Even though these isotherms discard no light on the method of the adsorption, they are helpful for evaluating results from different starting place on a quantitative origin, given that in order on the adsorption potential of a substance with effortlessly interpretable constants. At hand a number of isotherm equations obtainable for scrutinizing trial adsorption equilibrium statistics. In this job, the trial statistics were tested in Langmuir, Freundlich, Tempkin, Dubinin-Radushkevich, and Halsey isotherm models.

\section{Langmuir Isotherm}

Langmuir isotherm ${ }^{16}$ is signify by the subsequent equation:

$$
\frac{C_{e}}{q_{e}}=\frac{1}{Q_{o} K_{L}}+\frac{C_{e}}{Q_{o}}
$$

Wherever, the energy of adsorption $\left(\mathrm{Lmg}^{-1}\right)$ is related to the $b, \mathrm{C}_{\mathrm{e}}$ is the equilibrium dye concentration in solution $\left(\mathrm{mgl}^{-1}\right)$ and $\mathrm{Q}_{0}$ is a constant related to monolayer adsorption capacity ( $\left.\mathrm{mgg}^{-1}\right)$. A plot (Graph$5 \mathrm{a} \& \mathrm{~b})$ of $\mathrm{C}_{\mathrm{e}} / \mathrm{Q}_{\mathrm{e}}$ versus $\mathrm{C}_{\mathrm{e}}$ should indicate a straight line of slope $1 / \mathrm{Q}_{0}$ and an intercept of $1 /\left(\mathrm{K}_{\mathrm{L}} \cdot \mathrm{Q}_{0}\right)$ and are presented in Table.- 1 and 2. The essential characteristics of Langmuir Isotherm can also be described by a dimensionless separation factor $\mathrm{R}_{\mathrm{L}}$ which is defined by the following equation-

$$
\mathrm{R}_{\mathrm{L}}=\frac{1}{1+K_{L} C_{0}}
$$

Where $\mathrm{C}_{0}$ is the initial dye concentration $\left(\mathrm{mgL}^{-1}\right)$ and $\mathrm{K}_{\mathrm{L}}$ is the Langmuir constant. $\mathrm{R}_{\mathrm{L}}$ value among 0 to 1 designate favorable adsorption.

$$
\begin{array}{ll}
\mathrm{R}_{\mathrm{L}}>1 & \text { Unfavourable adsorption } \\
0<\mathrm{R}_{\mathrm{L}}<1 & \text { Favourable adsorption } \\
\mathrm{R}_{\mathrm{L}}=0 & \text { Irreversible adsorption } \\
\mathrm{R}_{\mathrm{L}}=1 & \text { Linear adsorption }
\end{array}
$$

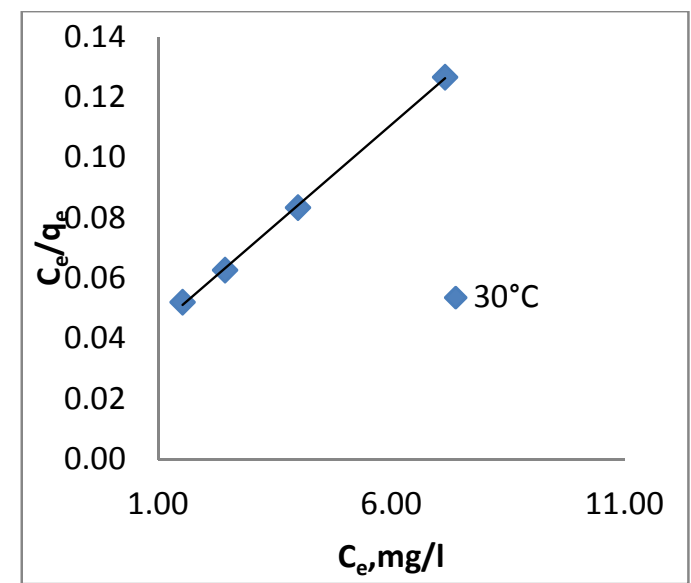

Graph-5a: Langmuir plot for the Malachite Green onto $\mathrm{AC}-\mathrm{MnO}_{2}-\mathrm{NC}$

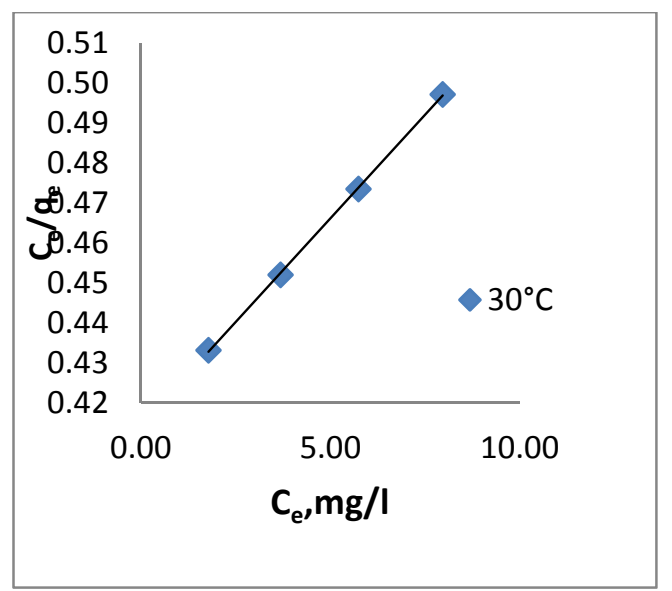

Graph-5b: Langmuir plot for the Reactive Red 4 onto $\mathrm{AC}-\mathrm{MnO}_{2}-\mathrm{NC}$ 
RASĀYAN J. Chem.

Vol. 11 | No. 4 |1423 - 1432| October - December | 2018

\section{Freundlich Isotherm}

The Freundlich isotherm ${ }^{17}$ model is an exponential equation that applies to the adsorption on heterogeneous surfaces with the interaction between adsorbed molecules and is not restricted to the formation of a monolayer. This isotherm is symbolized by the equation:

$$
\log \mathrm{q}_{\mathrm{e}}=\left(\frac{1}{\mathrm{n}}\right) \log \mathrm{C}_{\mathrm{e}}+\log \mathrm{k}_{\mathrm{f}}
$$

Where, $\mathrm{C}_{\mathrm{e}}$ is the equilibrium dye concentration in solution $\left(\mathrm{mgL}^{-1}\right), \mathrm{q}_{\mathrm{e}}$ is the amount of dye adsorbed $(\mathrm{mg})$ at equilibrium, $\mathrm{k}_{\mathrm{f}}\left[\mathrm{mg} / \mathrm{g}(\mathrm{L} / \mathrm{g})^{1 / \mathrm{n}}\right]$ is the Freundlich constant, $\mathrm{k}_{\mathrm{f}}$ is related to the binding energy and $\mathrm{n}$ is the heterogeneity factor ( $\mathrm{n}$ is a measure of deviation from linearity of the adsorption). It indicates the degree of non-linearity between solution concentration and adsorption. The value of $\mathrm{k}_{\mathrm{f}}$ and $\mathrm{n}$ were calculated from the linear plot (Graph-6a\&b) of "log qe" versus "log Ce" and are presented in Table.1and 2.

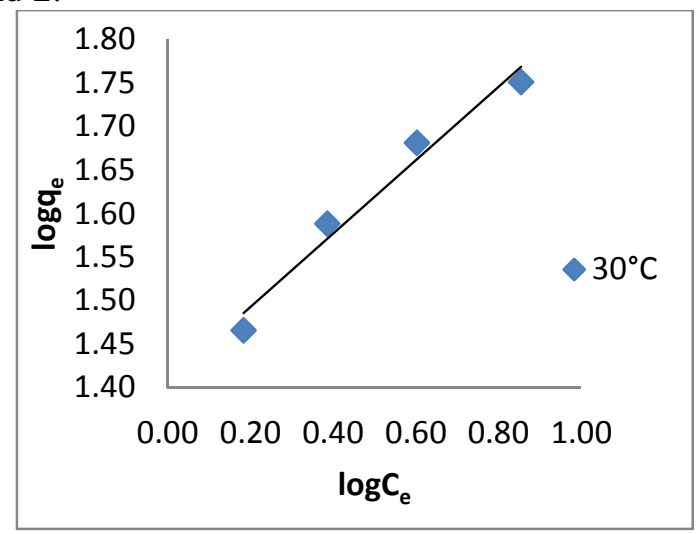

Graph-6a: Freundlich plot for the Malachite Green

\section{Tempkin Isotherm} onto $\mathrm{AC}-\mathrm{MnO}_{2}-\mathrm{NC}$

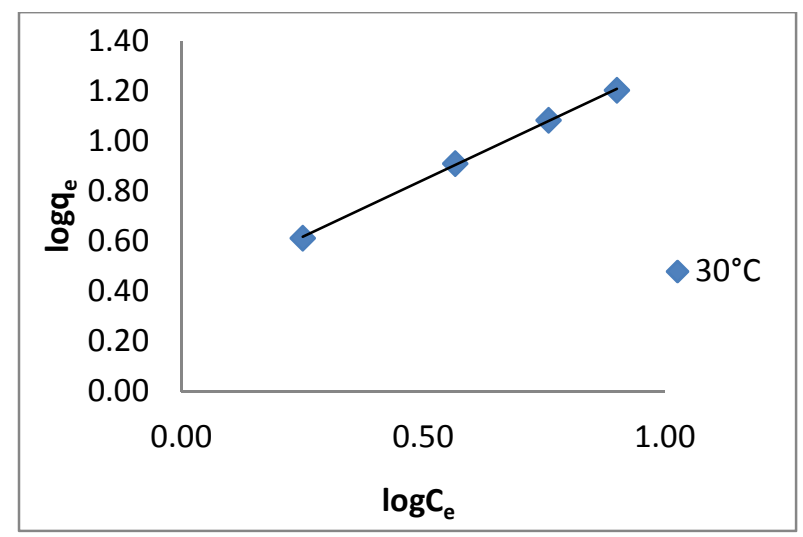

Graph-6b: Freundlich plot for the Reactive Red 4 onto AC$\mathrm{MnO}_{2}-\mathrm{NC}$

Tempkin isotherm ${ }^{18}$ takes into account the effect of indirect adsorbate-adsorbate interaction on adsorption and suggests that the heat of adsorption of all molecules in the adsorbent surface layer would decrease linearly with coverage. The Tempkin isotherm can be articulated in its linear form as-

Tempkin isotherm is represented by the following equation:

$$
\begin{aligned}
& \mathrm{q}_{\mathrm{e}}=\mathrm{RT} / \mathrm{b} \ln \mathrm{A}+\mathrm{RT} / \mathrm{b} \ln \mathrm{C}_{\mathrm{e}} \\
& \mathrm{q}_{\mathrm{e}}=\mathrm{B} \ln \mathrm{A}+\mathrm{B} \ln \mathrm{C}_{\mathrm{e}}
\end{aligned}
$$

Where $\mathrm{B}=\mathrm{RT} / \mathrm{b}$

The adsorption data can be investigated as said by equation (8). A plot of $\mathrm{q}_{\mathrm{e}}$ versus $\ln \mathrm{C}_{\mathrm{e}}$ facilitate the purpose of the isotherm constants A and B and it is revealed in Graph-7a\&b. Constant B is related to the heat of adsorption and $\mathrm{A}$ is the equilibrium binding constant $(1 / \mathrm{mol})$ corresponding to the maximum binding energy and values of the factor are agreed in Table-1 and 2.

\section{Dubinin-Radushkevich (D-R) Isotherm}

The $\mathrm{D}-\mathrm{R}^{19}$ model was also applied to determine the nature of the adsorption processes as either physical or chemical. The (D-R) isotherm is used to estimate the adsorption energy. This isotherm model is more general than Langmuir because it does not assume a heterogeneous surface or a constant adsorption potential. D-R model has commonly been applied in the following form-

$$
\ln \mathrm{q}_{\mathrm{e}}=\ln \mathrm{q}_{\mathrm{D}}-\mathrm{B}_{\mathrm{D}} \varepsilon^{2}
$$

Where $\mathrm{q}_{\mathrm{D}}$ is the $\mathrm{D}-\mathrm{R}$ constant representing theoretical saturation capacity (monolayer adsorption capacity) $(\mathrm{mg} / \mathrm{g})$, and $\mathrm{B}_{\mathrm{D}}$ is the D-R isotherm constant of the sorption energy $\left(\mathrm{mol}^{2} / \mathrm{KJ}^{2}\right)$, which is related to the $(\varepsilon)$ average energy of sorption per mole of the sorbate as it is transferred to the surface of the solid from an infinite distance in the solution ${ }^{20}, \mathrm{q}_{\mathrm{e}}$ is the amount of dye adsorbed in the adsorbent at equilibrium $(\mathrm{mg} / \mathrm{g})$. 
RASĀYAN J. Chem.

Vol. 11 | No. 4 |1423 - 1432| October - December | 2018

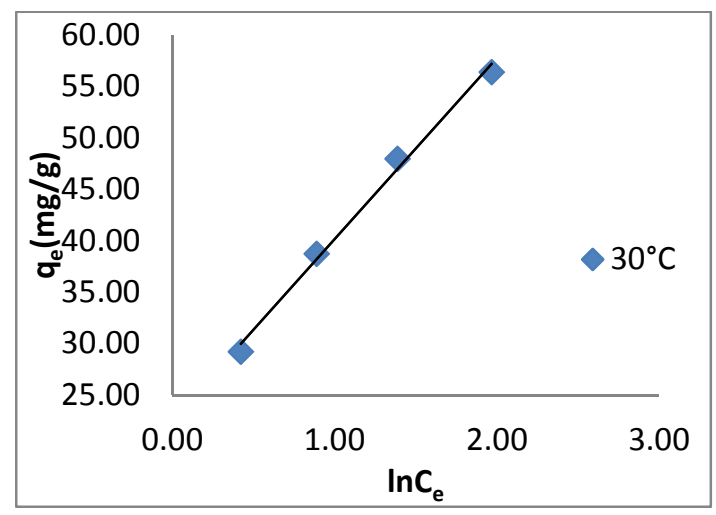

Graph-7a: Tempkin plot for the Malachite Green onto $\mathrm{AC}-\mathrm{MnO}_{2}-\mathrm{NC}$

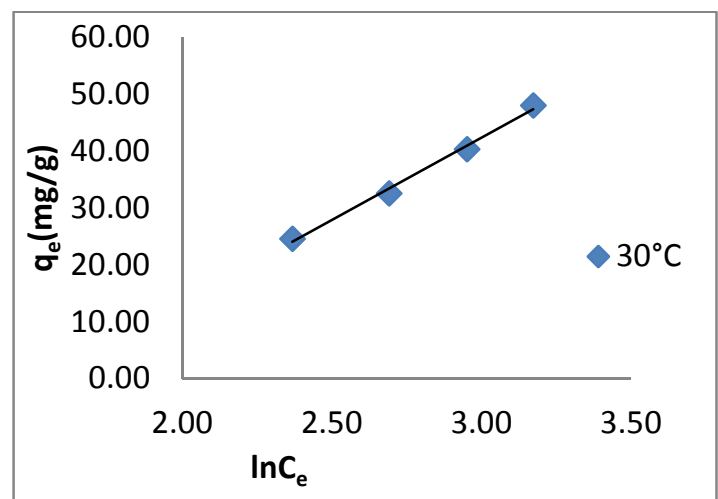

Graph-7b: Tempkin plot for the Reactive Red 4 onto $\mathrm{AC}-\mathrm{MnO}_{2}-\mathrm{NC}$

The parameter $\varepsilon$ is the Polanyi ${ }^{21}$ potential, which can be attained by:

$$
\varepsilon=\mathrm{RT} \ln \left(1+\frac{1}{C_{e}}\right)
$$

Where $\mathrm{R}$ is the gas constant, which is equal to $8.314 \mathrm{~J} / \mathrm{mol} \mathrm{K}$ and $\mathrm{T}$ is the solution temperature(K).

The average energy, $\varepsilon(\mathrm{kJ} / \mathrm{mol})$, can be calculated by using the $\mathrm{D}-\mathrm{R}$ parameter $\mathrm{B}_{\mathrm{D}}$ :

$$
\varepsilon=\frac{1}{\sqrt{2 B_{D}}}
$$

Based on this energy of activation one can predict whether an adsorption is a pHysisorption or chemisorption. If the value of $\mathrm{E}$ lies between 8 and $16 \mathrm{~kJ} / \mathrm{mol}$ the sorption process is a chemisorption one, while values of below $8 \mathrm{~kJ} / \mathrm{mol}$ indicate a physical adsorption process ${ }^{22}$. The plot of $\operatorname{lnq}_{\mathrm{e}}$ against $\varepsilon^{2}$ is revealed in Graph-8a and $8 b$. and the constants $\mathrm{q}_{\mathrm{D}}$ and $\mathrm{B}_{\mathrm{D}}$ were intended from the slope and intercept correspondingly. The D-R isotherm parameters are set in Table-1and 2. This plot also indicated from the regression parameter $\left(\mathrm{R}^{2}\right)$. The high-value $\mathrm{q}_{\mathrm{D}}$ show high adsorption capacity.

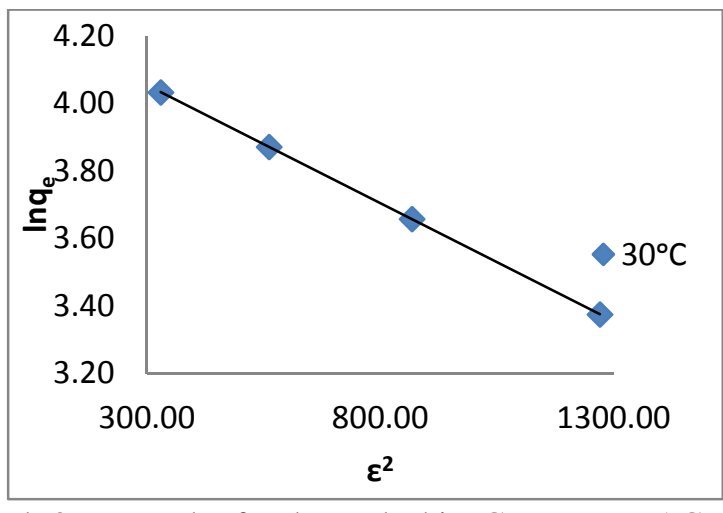

Graph-8a: D-R plot for the Malachite Green onto AC$\mathrm{MnO}_{2}-\mathrm{NC}$

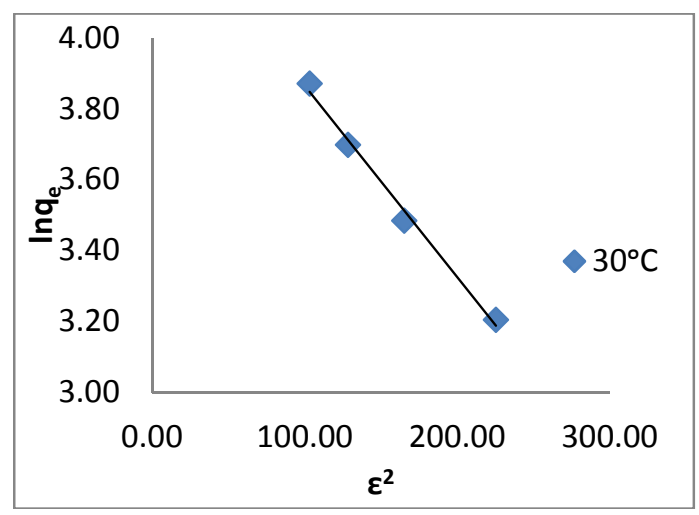

Graph-8b: D-R plot for the Reactive Red 4 onto AC$\mathrm{MnO}_{2}-\mathrm{NC}$

\section{Halsey Isotherm}

Halsey planned an expression for the concentration of a multilayer at a moderately huge distance from the surface $^{23}$,

$$
\mathrm{q}_{\mathrm{e}}=\left[\frac{K_{H}}{C_{e}}\right]^{1 / n} H
$$


RASĀYAN J. Chem.

Vol. 11 | No. 4 |1423 - 1432| October - December | 2018

This can be linearised as:

$$
\operatorname{lnq}_{\mathrm{e}}=\frac{1}{n_{H} \ln K_{H}}-\frac{1}{n_{H} \ln C_{e}}
$$

The plot of $\operatorname{lnq}_{\mathrm{e}} \mathrm{vs} \ln \mathrm{C}_{\mathrm{e}}$ is exposed in Graph-9a and $\mathrm{b}$. and the constants $\mathrm{K}_{\mathrm{H}}$ and $\mathrm{n}_{\mathrm{H}}$ were premeditated from the slope and intercept correspondingly. This equation is apt for multilayer adsorption. Principally, the correct of the trial statistics to this equation prove to the hetero porous nature of the adsorbent. The Halsey isotherm parameter is specified in Table-1and 2.

\section{Analysis of Isotherms}

\section{Langmuir Isotherm}

In the current study, $Q_{o}$ value for MG is 90.9090 and $R R 4$ is 100.00 . The separation factor $R_{L}$ value among 0 to 1 designate the suitable adsorption. The $\mathrm{R}^{2}$ evaluation is close to unity which reached to good fitting into Langmuir isotherm.

\section{Freundlich Isotherm}

For both dyes, the values of $\mathrm{n}$ were among 1 to 10 point out cooperative adsorption ${ }^{24} \cdot \mathrm{R}^{2}$ value is close to unity which reached to good fitting into Freundlich isotherm.

\section{Temkin Isotherm}

$\mathrm{B}_{\mathrm{T}}-$ Heat of adsorption is related to the Temkin constant. The $\mathrm{B}_{\mathrm{T}}$ value for together the dyes are 20.94 and 28.95 indicates the temperature of adsorption increased.

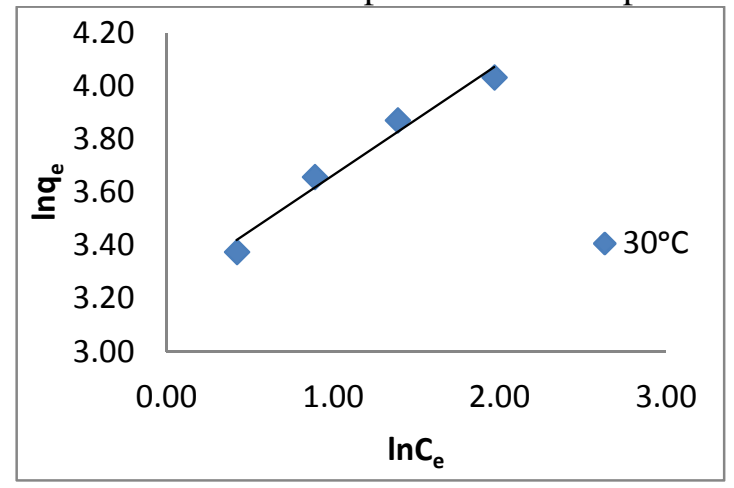

Graph-9a: Halsey plot for the Malachite Green onto $\mathrm{AC}-\mathrm{MnO}_{2}-\mathrm{NC}$

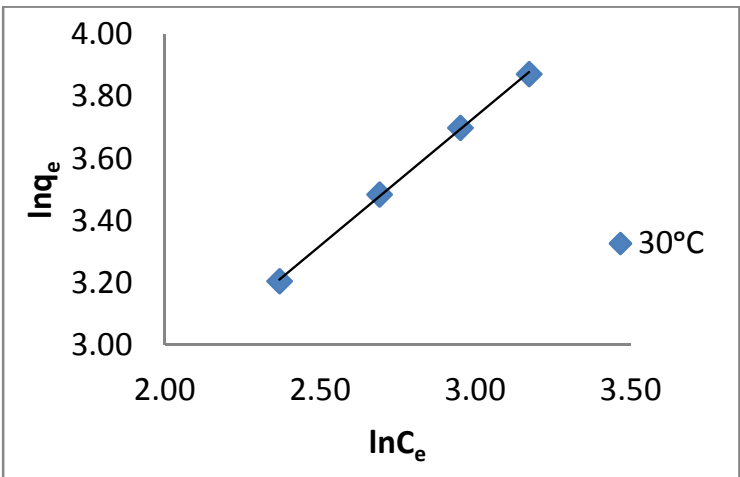

Graph-9b: Halsey plot for the Reactive Red 4 onto AC$\mathrm{MnO}_{2}-\mathrm{NC}$

Table. -1: Calculated isotherms parameters for the adsorption of $\mathrm{MG}$ onto $\mathrm{AC}-\mathrm{MnO}_{2}-\mathrm{NC}$

\begin{tabular}{|c|c|c|c|c|c|}
\hline \multirow{2}{*}{$\begin{array}{l}\text { Isotherm } \\
\text { Models }\end{array}$} & \multirow[t]{2}{*}{$\begin{array}{l}\text { Initial dye } \\
\text { concentration }\end{array}$} & \multicolumn{4}{|c|}{ Parameters and their results } \\
\hline & & $\mathrm{R}_{\mathrm{L}}$ & $\mathrm{b}$ & $\mathrm{Q}_{\mathrm{o}}(\mathrm{mg} / \mathrm{g})$ & $\mathrm{R}^{2}$ \\
\hline \multirow{4}{*}{ Langmuir } & 60 & 0.1812 & \multirow{4}{*}{0.0753} & \multirow{4}{*}{90.9090} & \multirow{4}{*}{0.999} \\
\hline & 80 & 0.1423 & & & \\
\hline & 100 & 0.1172 & & & \\
\hline & 120 & 0.0996 & & & \\
\hline \multirow[t]{5}{*}{ Freundlich } & $\begin{array}{l}\text { Initial dye } \\
\text { concentration }\end{array}$ & $\mathrm{n}$ & \multicolumn{2}{|c|}{$\begin{array}{l}\mathrm{K}_{\mathrm{F}} \\
\left(\mathrm{mg} / \mathrm{g}(\mathrm{L} / \mathrm{mg})^{1 / \mathrm{n}}\right)\end{array}$} & $\mathrm{R}^{2}$ \\
\hline & 60 & \multirow{4}{*}{1.3642} & \multirow{4}{*}{\multicolumn{2}{|c|}{11.0407}} & \multirow{4}{*}{0.997} \\
\hline & 80 & & & & \\
\hline & 100 & & & & \\
\hline & 120 & & & & \\
\hline \multirow[t]{2}{*}{ Temkin } & $\begin{array}{l}\text { Initial dye } \\
\text { concentration }\end{array}$ & $\mathrm{B}_{\mathrm{T}}$ & $\mathrm{A}_{\mathrm{T}}$ & $\mathrm{b}_{\mathrm{T}}$ & $\mathrm{R}^{2}$ \\
\hline & 60 & 20.94 & 0.6262 & 118.317 & 0.999 \\
\hline
\end{tabular}


RASĀYAN J. Chem.

Vol. 11 | No. 4 |1423 - 1432| October - December | 2018

\begin{tabular}{|c|c|c|c|c|c|}
\hline & 80 & & & & \\
\hline & 100 & & & & \\
\hline & 120 & & & & \\
\hline \multirow[t]{5}{*}{$\begin{array}{l}\text { Dubinin- } \\
\text { Radushkevich }\end{array}$} & $\begin{array}{l}\text { Initial dye } \\
\text { concentration }\end{array}$ & $\mathrm{B}_{\mathrm{D}}$ & $\mathrm{q}_{\mathrm{D}}$ & $\mathrm{E}$ & $\mathrm{R}^{2}$ \\
\hline & 60 & \multirow{4}{*}{$2 \times 10^{-3}$} & \multirow{4}{*}{71.0227} & \multirow{4}{*}{15.8113} & \multirow{4}{*}{0.999} \\
\hline & 80 & & & & \\
\hline & 100 & & & & \\
\hline & 120 & & & & \\
\hline \multirow[t]{5}{*}{ Halsey } & $\begin{array}{l}\text { Initial dye } \\
\text { concentration }\end{array}$ & $\mathrm{n}_{\mathrm{H}}$ & $\mathrm{K}_{\mathrm{H}}$ & & $\mathrm{R}^{2}$ \\
\hline & 60 & \multirow{4}{*}{2.3752} & \multirow{4}{*}{\multicolumn{2}{|c|}{1.1386}} & \multirow{4}{*}{0.970} \\
\hline & 80 & & & & \\
\hline & 100 & & & & \\
\hline & 120 & & & & \\
\hline
\end{tabular}

Table.- 2: Results of isotherm study for the adsorption of $\mathrm{RR} 4$ onto $\mathrm{AC}-\mathrm{MnO}_{2}-\mathrm{NC}$

\begin{tabular}{|c|c|c|c|c|c|}
\hline \multirow[t]{2}{*}{$\begin{array}{l}\text { Isotherm } \\
\text { Models }\end{array}$} & \multirow[t]{2}{*}{$\begin{array}{l}\text { Initial dye } \\
\text { concentration }\end{array}$} & \multicolumn{4}{|c|}{ Parameters and their results } \\
\hline & & $\mathrm{R}_{\mathrm{L}}$ & $\mathrm{b}$ & $\mathrm{Q}_{\mathrm{o}}(\mathrm{mg} / \mathrm{g})$ & $\mathrm{R}^{2}$ \\
\hline \multirow{4}{*}{ Langmuir } & 60 & 0.4088 & \multirow{4}{*}{0.0241} & \multirow{4}{*}{100.00} & \multirow{4}{*}{0.999} \\
\hline & 80 & 0.3424 & & & \\
\hline & 100 & 0.2932 & & & \\
\hline & 120 & 0.2569 & & & \\
\hline \multirow[t]{5}{*}{ Freundlich } & $\begin{array}{l}\text { Initial dye } \\
\text { concentration }\end{array}$ & $\mathrm{n}$ & $\begin{array}{l}\mathrm{K}_{\mathrm{F}} \\
(\mathrm{mg} / \mathrm{g}(\mathrm{L}\end{array}$ & & $\mathrm{R}^{2}$ \\
\hline & 60 & \multirow{4}{*}{1.0989} & \multirow{4}{*}{\multicolumn{2}{|c|}{2.4490}} & \multirow{4}{*}{0.999} \\
\hline & 80 & & & & \\
\hline & 100 & & & & \\
\hline & 120 & & & & \\
\hline \multirow[t]{5}{*}{ Temkin } & $\begin{array}{l}\text { Initial dye } \\
\text { concentration }\end{array}$ & $\mathrm{B}_{\mathrm{T}}$ & $\mathrm{A}_{\mathrm{T}}$ & $\mathrm{b}_{\mathrm{T}}$ & $\mathrm{R}^{2}$ \\
\hline & 60 & \multirow{4}{*}{28.95} & \multirow{4}{*}{4.5643} & \multirow{4}{*}{85.5810} & \multirow{4}{*}{0.994} \\
\hline & 80 & & & & \\
\hline & 100 & & & & \\
\hline & 120 & & & & \\
\hline \multirow[t]{5}{*}{$\begin{array}{l}\text { Dubinin- } \\
\text { Radushkevich }\end{array}$} & $\begin{array}{l}\text { Initial dye } \\
\text { concentration }\end{array}$ & $\mathrm{B}_{\mathrm{D}}$ & $\mathrm{q}_{\mathrm{D}}$ & $\mathrm{E}$ & $\mathrm{R}^{2}$ \\
\hline & 60 & \multirow{4}{*}{$5 \times 10^{-3}$} & \multirow{4}{*}{81.8591} & \multirow{4}{*}{10.000} & \multirow{4}{*}{0.992} \\
\hline & 80 & & & & \\
\hline & 100 & & & & \\
\hline & 120 & & & & \\
\hline \multirow[t]{5}{*}{ Halsey } & $\begin{array}{l}\text { Initial dye } \\
\text { concentration }\end{array}$ & $\mathrm{n}_{\mathrm{H}}$ & \multicolumn{2}{|l|}{$\mathrm{K}_{\mathrm{H}}$} & $\mathrm{R}^{2}$ \\
\hline & 60 & \multirow{4}{*}{1.2062} & \multirow{4}{*}{\multicolumn{2}{|c|}{0.5138}} & \multirow{4}{*}{0.999} \\
\hline & 80 & & & & \\
\hline & 100 & & & & \\
\hline & 120 & & & & \\
\hline
\end{tabular}

Dubinin-Radushkevich Isotherm

The activation energy $\mathrm{E}$ value of $\mathrm{MG}$ is 15.8113 and $\mathrm{RR} 4$ is 10.000 . $\mathrm{B}_{\mathrm{D}}$ value is $2 \times 10^{-3}$ and $5 \times 10^{-3}$ indicates the chemisorption.

\section{Halsey Isotherm}

The $\mathrm{R}^{2}$ value is close to unity which reached to good fitting into Halsey isotherm. 
RASĀYAN J. Chem.

Vol. 11 | No. 4 |1423 - 1432| October - December | 2018

\section{CONCLUSION}

The current research illustrates that $\mathrm{AC}-\mathrm{MnO}_{2}-\mathrm{NC}$ able to be used as an adsorbent for removal of Malachite Green and Reactive Red 4. The quantity of dye adsorbed varied with temperature, initial concentration, $\mathrm{pH}$ and adsorbent dose. The adsorption isotherm data well described by the following order: MG is Langmuir> Temkin> Dubinin-Radushkevich > Freundlich> Halsey and RR4 is Langmuir> Freundlich $>$ Halsey $>$ Temkin $>$ Dubinin-Radushkevich. This isotherm constant predicted that the highlevel monolayer adsorption and low-level multilayer adsorption. The study reveals to facilitate AC$\mathrm{MnO}_{2}-\mathrm{NC}$ is more efficient adsorbent for removing the Malachite Green and Reactive Red 4.

\section{REFERENCES}

1. C. M. Elinge, A.U. Itodo, I.J.Peni, U.A. Birnin-Yauri and A. N. Mbongo, Adv. Appl. Sci. Res, 2(4), 279(2011).

2. A. B. Yantus Neolaka, B. S. Eka Kalla, A. Gusti Malelak, K. Nia Rukman, Rasayan Journal of Chemistry, 11(2), 494(2018), DOI:10.31788/RJC.2018.1121994.

3. K. Venkata Ramana, K. Swarna Latha , K. Ravindranath and B. Hari Babu, Rasayan Journal of Chemistry, 10(2), 349(2017), DOI: 10.7324/RJC.2017.1021537.

4. S.Tamilselvi and M. Asaithambi, Rasayan Journal of Chemistry, 8(1), 84(2015)

5. M. Abul Hossain and R.M. Afiqur, Orbital Elec. J. Chem. Campo Grande, 4(3), 187(2012), DOI: 10.1186/1735-2746-9-2.

6. C. Theivarasu and S. Mylsamy, International J. of Eng. Sci.and Tech., 2(11), 6284(2010).

7. M. Aliabadi, I. Khazari, M. Hajiabadi and F.Shahrzad, J. Bio. \& Env. Sci., 2(9), 39(2012).

8. T. A. Khan, S. Sharma and I. Ali, J. Toxicol. Environ. Health Sci., 3(10), 286(2011), DOI: 10.5897/JTEHS.

9. A. Wttek-Krowiak, M. Mittek, K. Pokomeda, R. G. Szafran and S. Modelski, Chem. Process Eng., 31, 409(2010).

10. P. E. Kumar, Studies on characteristics and Fluoride removal capacity of Jambonut Carbon. M.PHil., Dissertation: Bharathiar University, Coimbatore, Tamilnadu, India (1991).

11. P.E. Kumar and V. Perumal, Nature Environment and Pollution, 9(3), 513(2010).

12. M. Sathya, P.E. Kumar and M. Santhi, International Journal of Science, Environment and Technology, 6(5), 2955(2017), DOI:10.15680/IJIRSET.2015.0402039.

13. M. El Haddad, R. Mamouni, N. Saffaj, and S. Lazar, Global J. Human. Soc. Sci., 12(10), 19(2012).

14. A. Jafar Ahamed, Removal of Lead by Adsorption Dynamics and Impact of Lead on the Fish Mastacembelus Armatus (Cuv. And Val), PH.D., Bharathidasan University(1998).

15. M. Ozacar and I. A. Sengil, Environ. Geol., 45, 762(2004).

16. I. Langmuir, Chem. Soc., 40(9), 1361(1918), DOI:10.1021/ja02242a004.

17. H. Freundlich, Z. Phys. Chemie., 57, 384 (1906), DOI:10.4236/ajac.2013.47A001.

18. M. J. Temkin and V. Pyzhev, Acta Physiochim URSS, 12(54), 217(1940), DOI: 10.4236/ojopm.2014.41004.

19. M. M. Dubinin, E. D. Zaverina and L.V. Radushkevich, J. Phy. Chem., 21, 1351(1947), DOI: 10.4236/jep.2011.26084.

20. S.Kundu and A.K.Gupta, Chem. Eng. J., 22(1-2), 93(2006), DOI:10.1016/j.cej.2006.06.002.

21. M. Polanyi, Verh. Deut. Phys. Ges., 16, 1012(1914), DOI: 10.1021/ef020104.

22. P. Sivakumar and P.N. Palanisamy, Int. J. Chem. Tech. Res., 1(3), 502(2009).

23. G.Halsey, J. Chem. Phys., 16, 931 (1948), DOI:10.1063/1.1746922.

24. K. Fytianos, E. Voudrias and E. Kokkalis, Chemosphere, 40(1), 3(2000).

[RJC-3066/2018] 